\title{
Correlation between prostate volume, prostate specific antigen level, prostate specific antigen density and age in the benign prostate hyperplasia patients
}

Djoko Rahardjo, Ponco Birowo, Levina Stephanie Pakasi

\begin{abstract}
Abstrak
Telah diteliti hubungan antara volum prostat, prostate specific antigen (PSA), prostate specific antigen density (PSAD) dan usia pada 873 pasien pembesaran prostat jinak. Rerata usia populasi penelitian adalah $65 \pm 8,8$ tahun, rerata volume prostat adalah $50 \pm$ $24,6 \mathrm{ml}$, yang lebih besar dibandingkan angka-angka dari negara-negara barat, Jepang dan Taiwan. Rerata kadar PSA adalah $12.9 \pm$ $18,2 \mathrm{ng} / \mathrm{ml}$ sedangkan rerata nilai $P S A D$ adalah $0,25 \pm 0,31$. Terdapat korelasi yang sedang antara volum prostat dengan usia, PSA dengan usia dan PSAD dengan usia. Koefisien korelasi Spearman masing-masing adalah $r=0,182, P<0.01 ; r=0.264, p<0.01, r=0.232$, $p<0.01$. Sedangkan korelasi yang kuat ditemukan antara nilai PSA dengan volum prostat (koefisien korelasi Spearman $r=0.502, p<0,01$ ). Kesimpulan: kadar PSA berhubungan erat dengan volum prostat pada pasien pembesaran prostat jinak. Nilai PSA dan PSAD pada penelitian ini jauh lebih tinggi dari negara lain yang memiliki insidens kanker prostat yang tinggi, hal ini memerlukan penelitian lebih lanjut untuk menentukan nilai normal PSA dan PSAD pada pasien pembesaran prostat jinak di Indonesia.
\end{abstract}

\begin{abstract}
We have investigated the relationship between prostate volume, prostate specific antigen (PSA), prostate specific antigen density (PSAD) and age in 873 patients with benign prostatic hyperplasia. The mean age was $65 \pm 8.8$ years, the mean prostate volumes were $50 \pm 24,6 \mathrm{ml}$, which is bigger compared to the data from western countries and also in Japan and Taiwan. The mean PSA level was $12.9 \pm 18,2 \mathrm{ng} / \mathrm{ml}$ and the mean PSAD in this study was $0.25 \pm 0,31$. There was a modest correlation between prostate volume - age, $P S A$ - age and PSAD - age, Spearman correlation coefficients were $r=0.182, p<0.01, r=0.264, p<0.01, r=0.232, p<0.01$ respectively and there was a strong correlation between PSA and prostate volume (Spearman correlation coefficient $r=0.502, p<0.01$ ). In conclusion, serum PSA level is strongly related to prostate volume in men with BPH with no evidence of prostate cancer. Since the PSA level and the PSAD in this study was higher than the other country with high incidence of prostate cancer, we need futher study to determine our own cut off level of PSA and PSAD in Indonesian benign prostate hyperplasia patiens.
\end{abstract}

Keywords: BPH, prostate volume, PSA, PSAD, age, correlation

Benign prostatic hyperplasia (BPH) is one of the common disease of ageing man. ${ }^{1}$ In Indonesia, BPH is the second most frequent disease found in urologic clinic. $^{2}$ Prostate specific antigen (PSA) is currently the most popular serum marker for prostate cancer. Serum PSA level is not cancer specific but rather prostate specific, therefore, sensitivity and specificity are suboptimal, especially at the intermediate level between 4.1 and $10.0 \mathrm{ng} / \mathrm{ml}$. For intermediate PSA levels, PSA density (PSAD) provide unique information regarding the need for biopsy and the likelihood of prostate cancer. $^{3,4}$ There was an ethnic variation in the level of PSA and PSAD, ${ }^{5}$ and some authors has investigate their

Division of Urology, Department of Surgery, University of Indonesia, School of Medicine/Dr. Cipto Mangunkusumo Hospital, Jaka: a, Indonesia own level of PSA and PSAD to enhance the usefullness for the detection of prostate cancer in their countries. ${ }^{6,7}$ As far as we know there were only very few study available concerning PSA and PSAD level in Indonesia.

The effect of benign prostatic hyperplasia on PSA levels is less understood. Both BPH and prostatic cancer are usually coexist in elderly patients suffering from prostate cancer. The effect of BPH on serum PSA levels is perhaps the main limitation of the use of PSA as a screening test for cancer. Study on the correlation between prostate volume, PSA level, PSAD and age of the patients with BPH has been performed in our center.

The purpose of this study is to know the correlation between prostate volume, PSA, PSAD and age in Indonesian patients. 


\section{METHODS}

A total of 873 patients included in this study was taken from our urology clinic in Dr. Cipto Mangunkusumo Hospital and Sumber Waras Hospital Jakarta between 1994 -1998, who were presented with clinical symptoms of bladder outflow obstruction due to BPH.

The inclusion criteria were patients with the diagnosis of BPH, no suspicious of malignancy on digital rectal examination (DRE) and transrectal ultrasonography (TRUS) by Pie Medical®, prostate specific antigen (PSA) $\leq 4 \mathrm{ng} / \mathrm{ml}$ or negative biopsy, maximum flow rate less than $10 \mathrm{cc} / \mathrm{second}$ measured by Dantec ${ }^{\circledR}$ Flowmeter, Madsen-Iversen symptom score more than 10. Any patient with an abnormal DRE result, elevated serum PSA level or suspicious lesion on TRUS was evaluated for a prostate malignancy.

The TRUS was performed similarly for all patients using a $7.5 \mathrm{MHz}$, multiplanar endorectal transducer from Pie Medical ${ }^{\circledR}$. In addition to assessing the echogenic pattern of the prostate gland, three measurements were also performed to calculate the prostate volume. The anterior-posterior (AP) and transverse (TR) diameters were measured at their respective maximal dimensions. The superior-inferior (SI) diameter was measured as the maximal length from the base to the apex of the prostate in the midline sagittal plane. The prostate volume was calculated using the formula of a prolate ellipsoid, Volume $=\pi \mathrm{p} / 6(\mathrm{TR} \times \mathrm{AP} \times \mathrm{SI}){ }^{8}$

The serum PSA concentration was determined using a solid phase, 2-site immunoradiometric assay (Tandem-R PSA; Hybritech). Blood samples were obtain before any prostate manipulations, including DRE and TRUS. DRE was performed by a senior staff urologist using the lithothomy position for all patients enrolled in this study.

\section{RESULTS}

The mean value of prostate volume, PSA, PSAD and age are presented in Table 1.

Table 1. Mean parameters

\begin{tabular}{lcc}
\hline Parameter & Mean & SD \\
\hline Age & 65 & 8.8 \\
Prostate Volume & 50 & 18.2 \\
PSA & 12.9 & 24.6 \\
PSAD & 0.25 & 0.31 \\
\hline
\end{tabular}

The mean age in this series was 65 years (SD 8.8, range 40 - 95), 20 (2.3\%) were between 40 and 49 years, 199 $(22.8 \%)$ were between $50-59$ years, $350(40.1 \%)$ were between 60-69 years, 247 (28.3\%) were 70-79 years, $51(5.8 \%)$ were between $80-89$ years, and $6(0.7 \%)$ were between $90-99$ years. Age group mean values for gland volume, PSA and PSAD are presented in Table 2.

Table 2. Age group mean value

\begin{tabular}{ccccc}
\hline $\begin{array}{c}\text { Age group } \\
\text { (years) }\end{array}$ & $\begin{array}{c}\text { No. } \\
{[\%]}\end{array}$ & $\begin{array}{c}\text { PSA (ng/ml) } \\
{[\mathrm{SD}]}\end{array}$ & $\begin{array}{c}\text { Prostate Volume } \\
(\mathrm{ml})[\mathrm{SD}]\end{array}$ & $\begin{array}{c}\text { PSAD } \\
{[\mathrm{SD}]}\end{array}$ \\
\hline $40-49$ & $20[2.3]$ & $6.36[10.03]$ & $28.31[10.60]$ & $0.19[0.27]$ \\
$50-59$ & $199[22.8]$ & $8.15[11.72]$ & $42.16[21.33]$ & $0.10[0.24]$ \\
$60-69$ & $350[40.1]$ & $13.31[19.05]$ & $55.49[25.59]$ & $0.23[0.30]$ \\
$70-79$ & $247[28.3]$ & $14.97[20.25]$ & $52.72[24.11]$ & $0.28[0.35]$ \\
$80-89$ & $51[5.8]$ & $20.06[20.66]$ & $52.98[24.42]$ & $0.40[0.42]$ \\
$90-99$ & $6[0.7]$ & $19.12[17.74]$ & $45.10[14.22]$ & $0.37[0.27]$ \\
\hline Total & $873[100]$ & $12.88[18.20]$ & $50.83[24.62]$ & $0.25[0.31]$ \\
\hline
\end{tabular}

The mean prostate volumes were $50 \mathrm{ml}$ (SD 24.6, range 9 - 149). The majority of the patients $(96.7 \%)$ had a prostate volume more than $20 \mathrm{ml}$. There was a modest correlation between prostate volume and age (Spearman correlation coefficient $\mathrm{r}=0.182, \mathrm{p}<0.01)$. The mean PSA level was $12.9 \mathrm{ng} / \mathrm{ml}$ (SD18.2, range 0.1 196.2). There were $299(34,2 \%)$ patients had PSA levels $\leq 4 \mathrm{ng} / \mathrm{ml} ; 247$ (28.3\%) had PSA levels between 4 and $10 \mathrm{ng} / \mathrm{ml}$ and $327(37.5 \%)$ had PSA levels $>10$ $\mathrm{ng} / \mathrm{ml}$. There was a modest correlation between PSA and age (Spearman correlation coefficient $r=0.264$, $p$ $<0.01$ ). There was a strong correlation between PSA and prostate volume (Spearman correlation coefficient $\mathrm{r}=0.502, \mathrm{p}<0.01$ ). (Figure 1). The mean PSAD in this study was 0.25 (SD 0.31, range 0.01-2.70. There was a modest correlation between PSAD and age (Spearman correlation coefficient $r=0.232, p<0.01$ ). The correlation between prostate volume, PSA level, PSAD and age are presented in Table 3.

Table 3. Comelation between parameters

\begin{tabular}{lll}
\hline Parameters & \multicolumn{1}{c}{ Age } & Volume \\
\hline PSAD & $r=0.232$ & $r=0.138$ \\
& $\mathrm{p}<0.01$ & $\mathrm{p}<0.01$ \\
PSA & $\mathrm{r}=0.264$ & $\mathrm{r}=0.502$ \\
& $\mathrm{p}<0.01$ & $\mathrm{p}<0.01$ \\
Volume & $\mathrm{r}=0.182$ & $*$ \\
\hline
\end{tabular}




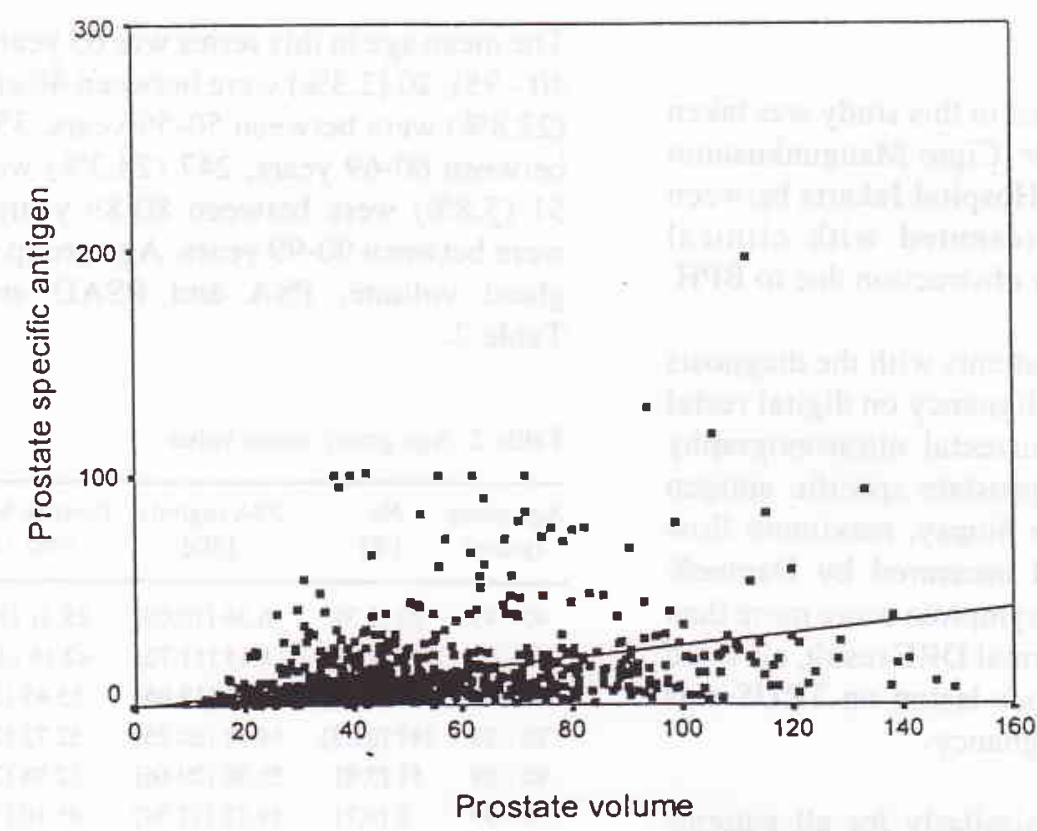

Figure 1. Plot of PSA by volume in 873 patients

\section{DISCUSSION}

Our study was performed on hospital based patients with clinically having BPH symptoms and proven no clinical evidence of prostatic cancer, by PSA level $\leq 4$ or by negative result in needle biopsy. This study provide a unique opportunity to present data on prostatic volume, serum PSA level and PSAD and age distribution in Indonesian BPH patients, so that we are able to define "normalcy" data for Indonesian patients. The association of benign enlargement of the prostate with age has been described in the community.

Our findings in prostate volume was higher than other publications. ${ }^{9,10}$ We found the mean prostate volume for all age was $50 \mathrm{ml}$. Collins et al. and Oesterling et al. Found $32 \mathrm{ml}$ and $29 \mathrm{ml}$ respectively and also bigger than in Japan and Taiwan, where the prostate volume are $35 \mathrm{ml}$ and $35 \mathrm{ml}$ respectively. This higher findings probably because our study was a hospital based study and Indonesian patients do not looking for medical service unless their condition is severe. This situation is due to the economic reason, and only a few of the patients covered by the insurance.

In our study, we found there was a modest correlation between prostate volume and age $(r=0,182, p<0.01)$. This finding is a little bit different with other studies. Collins ${ }^{9}$ et al. found a strong correlation between prostate volume and age $(r=0.44, p<0.001)$. Oesterling et al. $^{10}$ also found a strong correlation $(r=0.43$, $\mathrm{p}<0.0001$ ).

There was a big different of mean PSA level that we found compared to other publications. We found the mean PSA level was $12.9 \pm 18.0 \mathrm{ng} / \mathrm{ml}$. Other investigators only found the mean PSA level ranging from 0.03 to $3.70 \mathrm{ng} / \mathrm{ml}$ in BPH patients. ${ }^{9,10,11,12}$ The similar high mean PSA level was found also in $\operatorname{Japan}^{6}$ and Taiwan, ${ }^{7}$ where the incidence of prostate cancer like in Indoensia are also low. The mean PSA in Japan and Taiwan were $5.05 \pm 2.14$ and $7.7 \pm 3.1$ respectively. The modest correlation between PSA level and age that we found in this study $(r=0.263, p<0.001)$ is the same with what Collins et $\mathrm{al}^{9}$ and Oesterling ${ }^{10}$ found, $r=0.37, p<0.001$ and $r=0.43, p<0.0001$ respectively. In their study, Collins, ${ }^{9}$ Oesterling ${ }^{10}$ and Lepor, ${ }^{13}$ they fond a strong correlation between PSA level and volume with $\mathrm{r}=0.56, \mathrm{p}<0.001, \mathrm{r}=0.55, \mathrm{p}<0.0001$ and $r=0.119, p<0.001$ respectively. This study is similar to what we found in our series $(r=0.0502, p<0.01)$.

Other investigators have studied the PSAD. In our study, we found the mean of PSAD was $0.25 \pm 0.31$. The mean PSAD in other studies is different with our findings. They found the mean of PSAD range from $0.03-0.117 .^{9,10,11}$ And again this result was different in the country with low incidence of prostate cancer. In Japan, ${ }^{6}$ they found the mean PSAD was 0.17 and in 
Taiwan $^{7}$ was 0.27 . The correlation between PSAD and age in our study was simillar with other study. We found a modest correlation between PSAD and age $(\mathrm{r}=0.23, \mathrm{p}<0.01)$ where Collins and Oesterling found $r=0.22, p<0.001$ and $r=0.25 p<0.001$ respectively.

In conclusion, serum PSA level is strongly related to prostate volume in men with BPH without prostate cancer. Our mean PSA level and PSAD are much higher than result of the studies in western countries, but more or less similar with studies performed in countries with low incidence of prostate cancer such as Japan and Taiwan. Since the PSA level and the PSAD in this study was higher than the other country, we need futher study to determine our own cut off level of PSA and PSAD in Indonesian benign prostate hyperplasia patiens.

\section{REFERENCES}

1. Garraway WM, Collins GN, Lee RJ. High prevalence of benign hypertrophy in the community. Lancet 1991;338: 469-71.

2. Umbas R. Patofisiologi dan patogenesis pembesaran prostat jinak. Maj Kedok Indon 1996;46(1): 38-9.

3. Benson MC, Whang IS, Olsson CA, McMahon DJ, Cooner WH. The use of prostate specific antigen density to enchance the predicitive value of intermediate levels of serum prostate specific antigen. J Urol 1992;147: 817-21.

4. Benson MC, Olsson CA. Prostate specific antigen and prostate specific antigen density. Cancer 1994;74(6):1667-73.
5. Presti JC, Hovey R, Bhargava V, Carroll PR, Shinohara K. Prospective evaluation of prostate specific antigen and prostate specific antigen density in the detection of carcinoma of the prostate: ethnic variations. J Urol 1997;157:907-12.

6. Gohji K, Nomi M, Egawa S, Takenaka A, Okamoto M, et al. Detection of prostate carcinoma using prostate specific antigen, its density, and the density of the transition zone in Japanese men with intermediate serum prostate specific antigen concentration. Cancer 1997; 79 (10): 1969-76.

7. Yu HJ, Lai MK. The usefulness of prostate specific antigen (PSA) density in patients with intermediate serum psa level in a country with low incidence of prostate cancer. Urology 1998;51 Suppl 5A:125-30.

8. Terris K, Stamey TA. Determination of prostate volume by transrectal ultrasound. J Urol 1991;145:984-7.

9. Collins GN, Lee RJ, McKelvie GB, Rogers CN, Mehir M. Relationship between prostate specific antigen, prostate volume and age in the benign prostate. Br J Urol 1993; 71:445-50.

10. Oesterling JE, Jacobsen SJ, Chute CG, Guess HA, Girman CJ, Panser LA et.al. Serum prostate specific antigen in a community based population of healthy men. JAMA 1993;270 (7): 860 - 4 .

11. Benson MC, Whang IS, Pantuck A, Ring K, Kaplan SA, Olsson CA et al. Prostate specific antigen density: a means of distinghushing benign prostatic hypertrophy and prostate cancer. J Urol 1992;147: 815-6.

12. Roehborn CG, Boyle P, Gould AL, Waldstreicher. Serum prostate specific antigen as a predictor of prostate volume in men with benign prostatic hyperplasia. Urology 1999;53(3):581-9.

13. Lepor H, Shapiro W. Relationship between prostatic epithelial volume and serum prostate specific antigen levels. Urology 1994;44(2):199-205. 